\title{
The characteristic and evolution of coal-forming swamp in Hanshuiquan district, Santanghu Coalfield, Xinjiang, NW China, during the Middle Jurassic: evidence from coal petrography, coal facies and sporopollen
}

\author{
Shuo Feng ${ }^{1} \cdot$ Jing He$^{1} \cdot$ Jijun Tian $^{1}(\mathbb{D}) \cdot$ Xingyu Lu$^{1} \cdot$ Bo Yang $^{1}$
}

Received: 29 December 2017/Revised: 17 October 2018/Accepted: 30 November 2018/Published online: 7 January 2019

(C) The Author(s) 2019

\begin{abstract}
Santanghu Coalfield is the largest integrated coalfield exploration area in China. The major coal seams developing in Xishanyao Formation (Middle Jurassic) are the high-quality steam coals characterized by large thickness, favorable horizontal continuity and high coal quality. In this paper, twenty-two samples were collected from the three typical boreholes in Hanshuiquan district, representing the 11 coal seam sequences (7\#, 8\#, 9\#, 13\#, 14\#, 15\#, 17\#, 18\#, $19 \#, 20 \#, 22 \#)$, respectively. The petrographic characteristics of the coal-bearing sequence in Xishanyao Formation were firstly summarized systematicly, and then the coal-forming swamp characteristics and succession mechanism of the coal seam in Xishanyao Formation were defined by analyzing the samples. The maceral composition, structure, geochemical and geophysical characteristics of coal are included in original genetic criteria of coal-forming swamp analysis. And the composition of coal petrography, maceral and microlithotype are the most frequently used parameters. Coal is composed of microscopic constituents and inorganic substances. The Xishanyao Formation maceral mainly consists of vitrinite (65.74\%-97.01\%), inertinite (1.93\%-34\%), and the exinite shows the mode of regular change. The coal-forming swamp in Xishanyao Formation possesses the characteristics of mainly marsh, wet forest swamp facies, and shallow water covered forest swamp facies, and a few of coal seams distribute in the deep water covered forest swamp facies. In addition, the sporopollens in Xishanyao Formation are mainly Pinaceae evergreen broad leaf and needle-leaved plants, Osmundaceae, Cyatheaceae and Lygodiaceae, indicating that the warm and humid tropic-subtropical climate conductive to the persistent growth of coal-forming plants in the Middle Jurassic. The coal-forming swamp shows the characteristics of vertically upward fluctuation through the periodic transition. It indicates a shallow-deep-shallow change process of the water covered depth in the swamp. This is the principal factor for the formation of the high-quality and continuous coal seam in Hanshuiquan district, Santanghu Coalfield.
\end{abstract}

Keywords Santanghu Coalfield $\cdot$ Xishanyao Formation $\cdot$ Coal-forming swamp $\cdot$ Sporopollen

\section{Introduction}

The contents of ash and sulphur in high-quality coal developing in Jurassic System of northwest China are low (Huang et al. 2010), which is conducive to the development of industrial economy and ecological environment, and its

Jijun Tian

tianxju@yahoo.com

1 Institute of Geology and Mining Engineering, Urumqi 830002, Xinjiang, China most significant coal petrography characteristic is the abundance of inertinite. For instance, in eastern Junggar Coalfield, southern Junggar Coalfield, Ili Coalfield, the average content of the inertinite is more than $40 \%$ and even $70 \%$ in Middle Jurassic of Xishanyao Formation (Zhou et al. 2010; Li et al. 2012a, b, 2014; Dai et al. 2015a, b; Fu et al. 2016). The content of inertinite varies from $35 \%$ to 90\% in the Jurassic coal-bearing stratum, Muli Coalfield, Qaidam Basin (Dai et al. 2015a, b). The Jurassic coal in Erdos Basin is mainly rich-inertinite coal, and the average content of the inertinite in fluvial facies is above $40 \%$ (Du 
et al. 2009; Dai et al. 2012; Ao et al. 2012). However, this research found that the maceral of the coal petrography is mainly characterized by the abundant vitrinite in Hanshuiquan district, Santanghu Coalfield, Northwest China. Its average content is more than $80 \%$, while the content of inertinite is about $10 \%$ (Fig. 1). The cognition of the Jurassic coal in Northwest China is enriched by the vitrinite-rich coal in Santanghu Coalfield.

In this area, previous scholars have focused on the tectonic evolution, sequence stratigraphy, provenance, sedimentary, coal derived oils and tight oil of the basin, and their research areas is mainly located in Tiaohu sag and Malang sag (Wang et al. 2015, 2016; Liang et al. 2014; Liu et al. 2015). The coal-derived oils were discovered in Xishanyao Formation in the Well Tangcan-1 (Zhang et al. 2000). In term of the provenance and sedimentary environment, the Jurassic sedimentary system of Santanghu Coalfield was systematically studied by Jiang (2003). He found that the Jurassic provenance of Santanghu Coalfield is characterized by near source, short flow and multiple sources, developing delta-lacustrine depositional system. Huang (2002) carried out a detailed analysis on the sporopollen of Xishanyao Formation at Well Tangqian-3 in Santanghu Coalfield, and recognized the palynological assemblage characteristics of Cyathidites minor- Osmundacidites- Cycadopites- Quadraeculin, which reflectes the temperate or subtropical climate in middle Jurassic.

However, the researches on coal petrography, coal facies and coal-forming swamp in Santanghu Coalfield are inadequate. In term of coal petrography and coal quality, the suberinite was first discovered by $\mathrm{He}$ et al. (1995) in Santanghu Coalfield through the research of coal petrography. An and Ma (2013) studied the No. 9 coal seam at Hanshuiquan and Tiaohu sags in Santanhu, and judged that it is the long flame coal characterized by low or extremely low ash, high volatiles, extremely low sulfur, high calorific value, high thermo stability, easy selection, high content of arsenic, extremely low chloride, low phosphorous, low fluorine, and high content of oil. A preliminary study on the arsenic in Santanghu coal field was carried out by Huang (2014), and pointed out that arsenic is abundant in the pyrite. In term of the coalforming swamp, Chinese coal geology scholars studied the coal-forming swamps of the Jurassic coal accumulating basins in the north of Xinjiang since 2010. For instance, Nie et al. (2016) pointed out that the coal-forming swamp in Turpan-Hami Basin is mainly comprise of wetland marsh facies and wetland forest swamp facies. $\mathrm{Li}$ et al. (2012a, b) deemed that the coal-forming swamp mainly consists of dry forest swamp facies and wetland forest swamp facies in eastern Junggar coalfield. Alimujiang et al. (2014) considered that the coal-forming swamp is mainly composed of wetland swamp facies and wet forest swamp facies in southern Junggar coalfield. Zhang et al. (2015) studied the Jurassic coal-forming swamp in Santanghu, and believed that the major coal seam in Xishanyao Formation is transited from wide water marsh to wet forest swamp, and through the research of its coal petrography and coalforming swamp, he found that exinite content is zero. This might be resulted from the small quantity of sample, which fails to accurately reflect the evolutionary characteristics of the coal-forming swamp in this area. For this reason, the major coal seams in Hanshuiquan district, Santanghu Coalfield are selected to study the coal-forming swamp

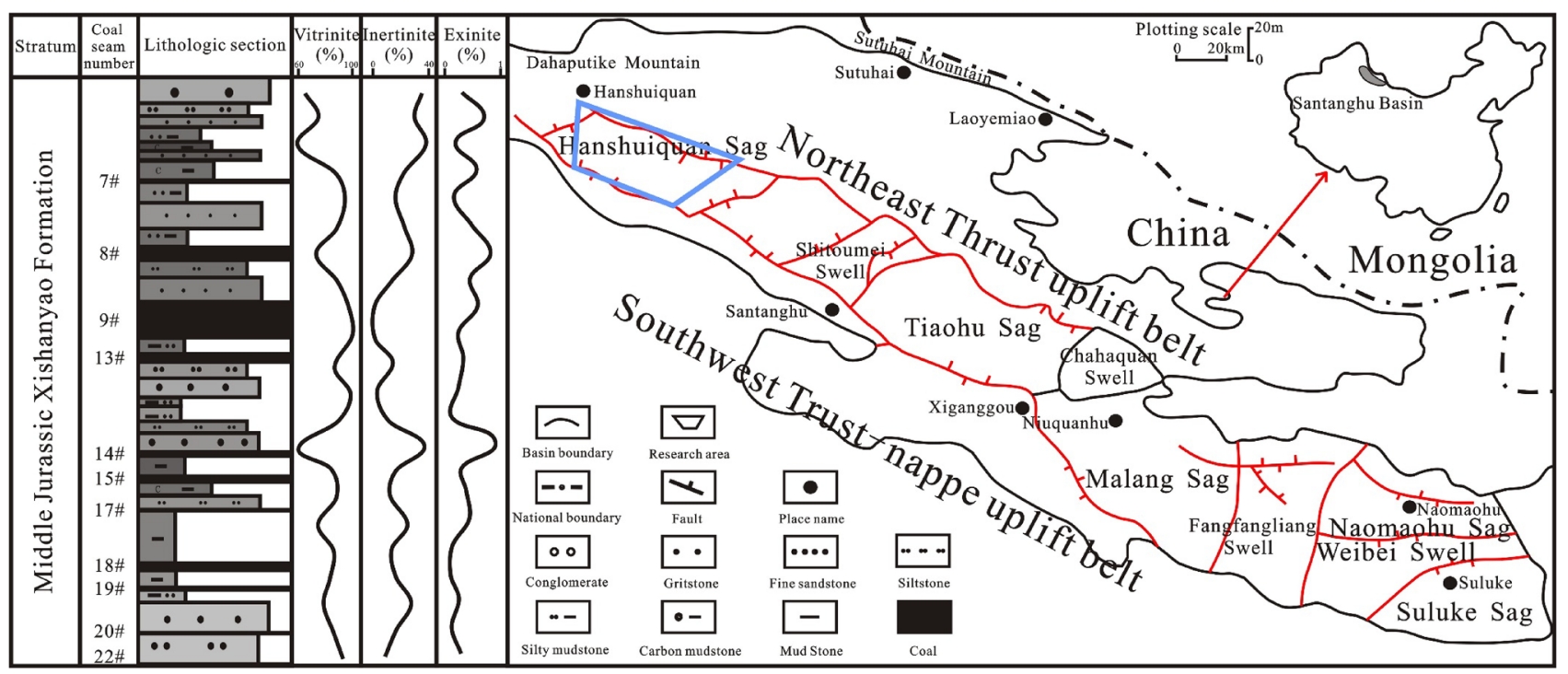

Fig. 1 The research area location, the lithotype distribution and the change tendency of samples macerals in Xishanyao Formation, Hanshuiquan district, Santanghu Coalfield, NW China 

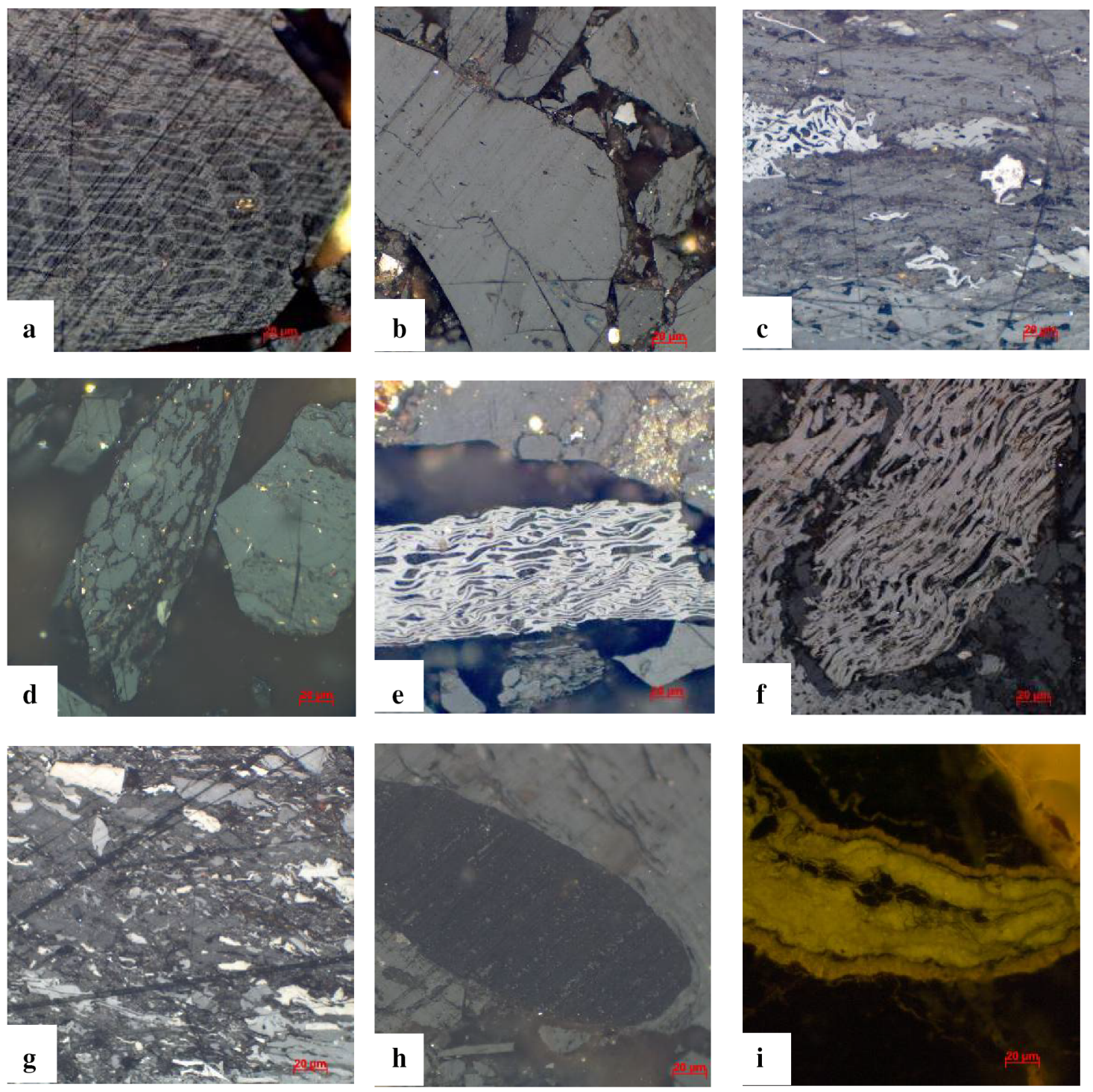

Fig. 2 Photomicrographs in white reflected light (oil immersion) (a-h) and fluorescing-inducing blue light (i) coal seams in Santanghu Coalfield. a Telinite showing well-preserved cell structure; b Telocollinite with inertodetrinite; c Desmocollinite with semifusinite; d Corpocollinite with pyrite; $\mathbf{e}$ the cell cavity of Fusinite filled with vitrodetrinite; f Semifusinite with desmocollinite; $\mathbf{g}$ Vitrodetrinite and inertodetrinite; $\mathbf{h}$ Resinite in the shape of ellipsoid; $\mathbf{i}$ Sporinite of the shape flat ring

characteristics and evolution rules. Moreover, this paper makes a comparison with the previously studied on coalforming swamp of Xishanyao Formation in Xinjiang to study the type and characteristic of coal-forming swamp and its evolution characteristic in Xishanyao Formation (Teichmüller and Teichmüller 1982).

\section{Geological setting}

Santanghu Coalfield is located at Barkol County and Yiwu County, Northeast Xinjiang Province, with a strip shape oriented NW-SE between Moqinwula and Suhaitu Mountains (Liu et al. 2012a, b; Song et al. 2013; Ge et al. 2015;
Hackleya et al. 2016). Santanghu Coalfield is the largest integrated Coalfield prospecting area in Xinjiang and even in China. Before 2012, 37,392,727,400 tons of coal reserves buried in the exploration depth of $<1000 \mathrm{~m}$, has been prospected in Xishanyao Formation (No. 2-20 coal seams) of middle Jurassic, and the coal reserves buried in the exploration depth of $<2000 \mathrm{~m}$ is 120 billion tons. It provides a sound energy resource support to the implementation of "Transport coal from Xinjiang to Eastern China" and "Transport electricity from Xinjiang to Eastern China" (Huang and Tian 2013).

The Hanshuiquan district is located in the northwest of the Central depression belt (Fig. 1), north of the Baruntala anticline, extending to the Shaheba fault, and it is the 


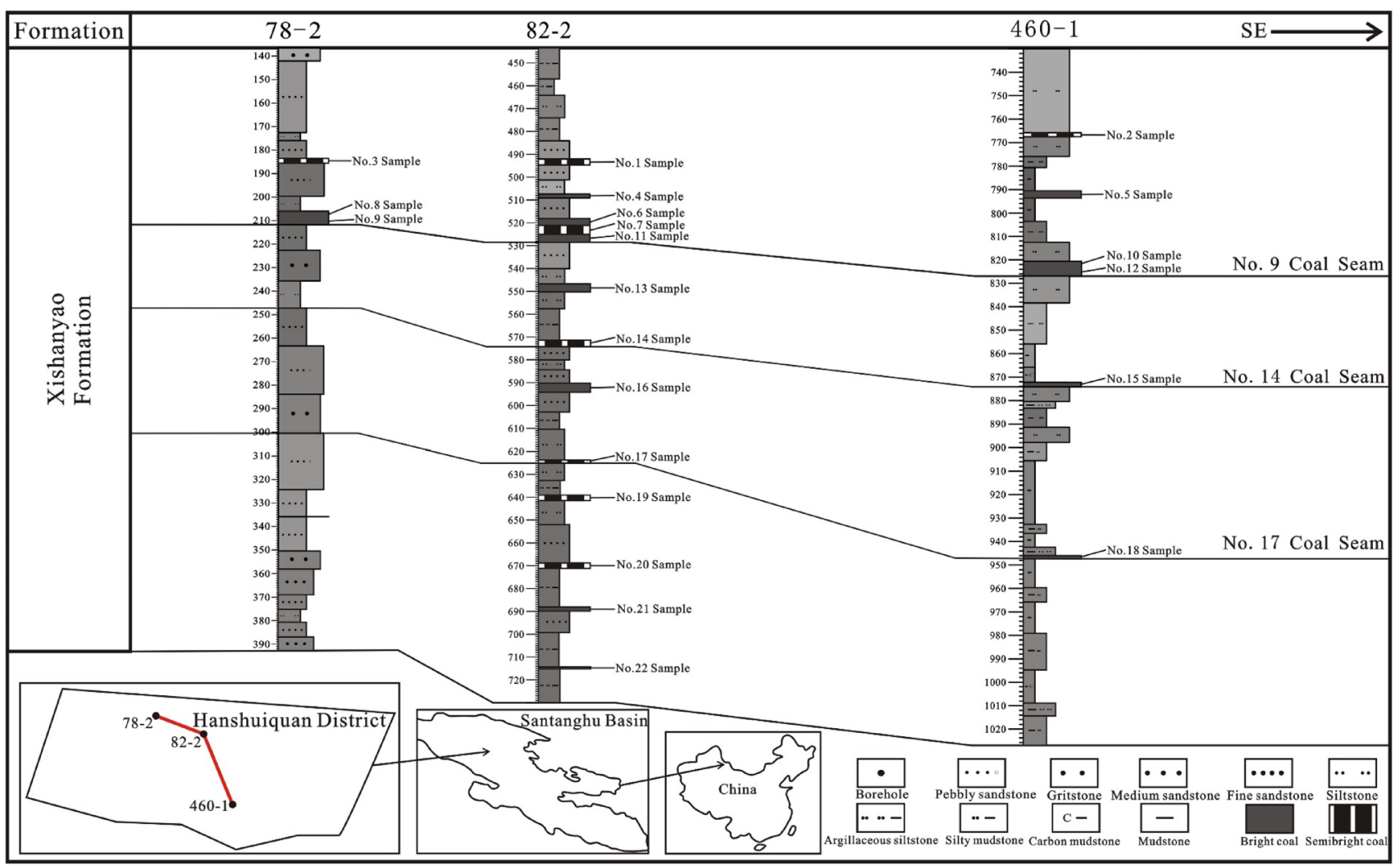

Fig. 3 The connecting-well section of 78-2, 82-2, 460-1 and the location of samples collection

largest two-stage tectonic unit in the basin (Xiao et al. 2004a, b; Ma et al. 2016a, b). The acreage of Hanshuiquan district is about $750 \mathrm{~km}^{2}$, with length of $60 \mathrm{~km}$ in eastwest direction, width of $10 \mathrm{~km}$ in south-north direction. The overall terrain is high in the northwest and low in the southeast. The surface covers the Quaternary gravel and sandy loam. The outcrop of Xishanyao Formation sporadically can be discovered in the southwest of the Hanshuiquan district. The major lithology of Xishanyao Formation is mainly in kelly, celadon mudstone, siltstone mixed up with sandstone, coal seam and spathic iron. The bottom is mainly in large-coarse conglomerate and medium-coarse sandstone. There are a total of twenty-two coal seams in Xishanyao Formation, in the upper three coal seams are sporadically developed and their thickness is small. The lower coal seams distribute in the whole area and the thickness of No. 9 coal seam is more than $30 \mathrm{~m}$ in particular, the thicknesses of other coal seams are less than $5 \mathrm{~m}$ (Fig. 2).

\section{Sampling and experimental methods}

Twenty-two samples from eleven coal seams were systematically collected from three typical boreholes (78-2, 82-2 and 460-1) in Hanshuiquan district, Santanghu
Coalfield. Three pieces of samples (No. 3, No. 7, No. 9) in the 78-2 borehole were collected from the No. 7 and No. 9 coal seams. Six pieces of samples (No. 2, No. 5, No. 10, No. 12 , No. 15 , No. 18) in 460-1 borehole were collected from No. 7, No. 8, No. 9, No. 14 and No. 17 coal seams. Thirteen pieces of samples (No. 1, No. 4, No. 6, No. 8, No. 11 , No. 13 , No. 14 , No. 16 , No. 17 , No. 19 , No. 20 , No. 21 , No. 22) in 82-2 borehole were collected from the eleven coal seam sequences $(7,8,9,13,14,15,17,18,19,20,22)$ (Fig. 3).

The samples of each coal seam were divided into two parts. Smash one part and divide by the screen drum with the diameter of $1.0 \mathrm{~mm}$, create into the briquette polished section for the maceral authentication and the vitrinite reflectance measurement. The coal polished section was prepared according to the ISO 7404-2 (2009). The classification and the quantitative analysis of maceral were carried out according to the ISO 7404-1 (1994). In the recognition and quantitative statistics of maceral and minerals, the observed effective points should be more than 500. The other parts of samples were sent to State Key Laboratory of Palaeobiology and Stratigraphy in Nanjing Institute of Geology and Palaeonotology for the identification of sporopollen and the statistics of the number. 


\section{Characteristics of coal petrography}

\subsection{Characteristics of coal macrolithotype and petrography}

The macrolithotype of coal in Xishanyao Formation is mainly made up of bright coal, semibright coal and a little dull coal. The fracture is in the shape of conchoid and irregularity. No. 8, 13, 15, 20 and 22 coal seams are made up of bright coal, No. 7, 18 and 19 coal seams are made up of dull coal, No. 9, 14 and 17 coal seams are made up of bright coal and semibright coal together. The bright coal is developed in the coal seams with banded and lentoid shape, and poor horizontal continuity. The banded structure of the semibright coal is more significant, showing the interbedding between the bright part and the dark part. Siderite, pyrite, calcite, clay and other inorganic minerals, which are developed in the coal seam or filled in the fracture and bedding surface with the shape of granulous, lentoid and concretion.

\subsection{Characteristics of microscopic coal petrography}

The results of maceral analysis had been summarized in Table 1. Vitrinite is the most significant maceral in the twenty-two samples with averaging $88.21 \%$, varies from $65.74 \%$ to $97.01 \%$. And the content of the vitrinite in most samples varies from $70 \%$ to $90 \%$. The vitrinite is mainly composed of telocollinite and desmocollinite, showing the vertically upward fluctuation trend. The content of the inertinite varies from $1.93 \%$ to $34 \%$, which only inferior to the vitrinite in the coal samples. The content of the inertinite in most samples varies from $10 \%$ to $30 \%$, which is mainly made up of semifusinite. Particularly, the contents of the inertinite at the bottom of No. 7 coal seam (No. 3 sample) and the top of No. 14 coal seam (No. 14 sample) are up to $30 \%$, which can be attributed to the sufficient oxygen supply inducing by the shallow water coverage and be exposed in air. The exinite is distributed sporadically in local samples, and the content varies from $0.11 \%$ to $0.92 \%$. It is characterized by obvious fluorescence. The exinite shows dark grey-black in the reflected light of the oil immersion and yellow fluorescence in blue excitation light source. Sporophore and resinite have been discovered in the exinite in this research area. The former is in the shape of helminth and flat ring, and the latter shows ellipsoid distribution (Fig. 2). In general, the content of vitrinite in bright coal is more than $80 \%$, and in semibright coal is more than $60 \%$ (Fig. 2).

The maceral components of coal samples in the research area are compared with the those of the coal in some large fault basins in China (such as Fushun, Meihekou,
Xiaolongtan, and Fuxin basin). The results show that the maceral contents of the coal petrography in Xishanyao Formation at Hanshuiquan district in Santanghu Coalfield are closed to the maceral contents of those fault basins. Due to the relatively rapid basal deposition rate in the fault basin, the coal-forming swamp is covered by deep water and buried rapidly. This lead to a high vitrinite content (Pang et al. 2012).

There have differences in the macerals of Middle Jurassic coal seams. For instance, the average content of vitrinite is $50 \%$ in Heshituoluogai Coalfield, varies from $1.45 \%$ to $95.3 \%$ in eastern Junggar area, higher than $87 \%$ in Balikun, varies from $56.1 \%$ to $93.4 \%$ in southern Junggar area, varies from $21.5 \%$ to $49 \%$ in western Junggar, and varies from $26.9 \%$ to $35.7 \%$ in Fukang local district (Wei 2002).

The content of inertinite generally varies from $53.9 \%$ to $83.1 \%$ in eastern Junggar area, and the content is decreased to $2.9 \%-10.8 \%$ in Barkol area. In contrast, the content of inertinite from the Fukang Sangonghe area to Urumqi Liudaowan is up to $38.5 \%-66.9 \%$. The contents vary from $1.1 \%$ to $6.1 \%$ in Liuhuanggou area (Wei 2002). Inorganic minerals such as siderite, pyrite, calcite and clay can be seen in the coal seam or filling the cracks and bedding with the shap of granular, lenticular and nodular morphology. Clay minerals mainly contain kaolinites and illites, which distribute in disseminated or thin stratified structure (Zhang et al. 2018) (Fig. 4).

There is low content of exinite in Xinjiang. The exinite was not be discovered by $\mathrm{Li}$ et al. (2012a, b) in eastern Junggar coalfield according to the mathematical statistics of coal petrography maceral. Compared with the major coal-producing area in Xinjiang, the coal petrography maceral of Xishanyao Formation at Hanshuiquan district in Santanghu coalfield is characterized by abundant vitrinite and a little content of inertinite and lower exinite.

\section{Characteristics of coal-forming swamp}

\subsection{The coal-forming swamp characteristics and analysis}

The coal-forming swamp is generally analyzed through TPI (tissue preservation index), GI (gelatification index) (Diessel 1982; Kalkreuth et al. 1991, 2000; Kalaitzidis et al. 2009), GWI (groundwater influence index), VI (vegetation index) (Calder et al. 1991; Gmur and Kwiecinska 2002; Dai et al. 2007) and T-D-F triangular diagram. In addition, V/I (vitrinite/inertinite), WI (woodland index), F/M (framewok/matrix), OI (oxidization index) (Gorbanenko and Ligouis 2015), TI (transfer index), BI (breaking index), MI (mobility index) were adopted to 


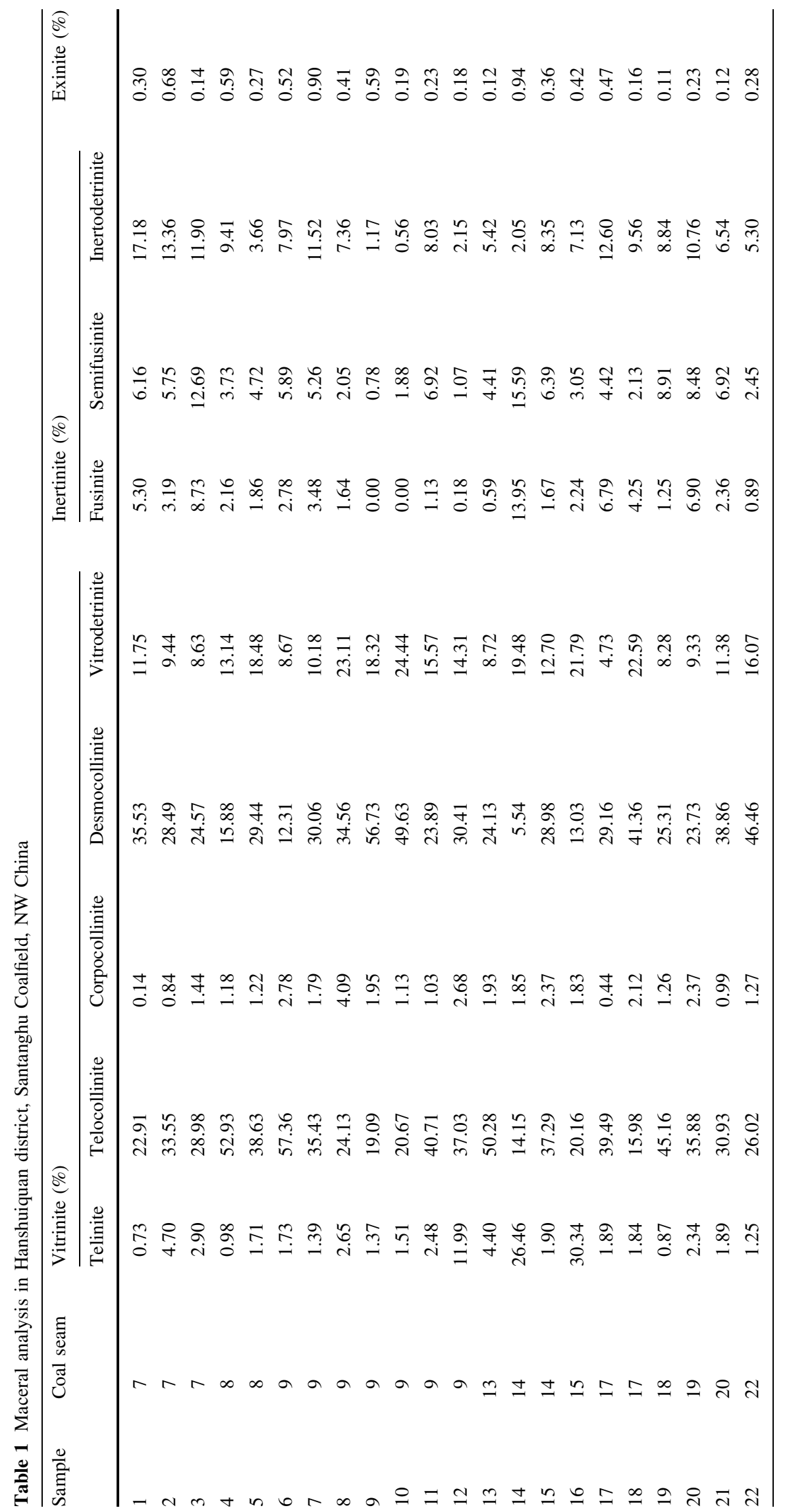



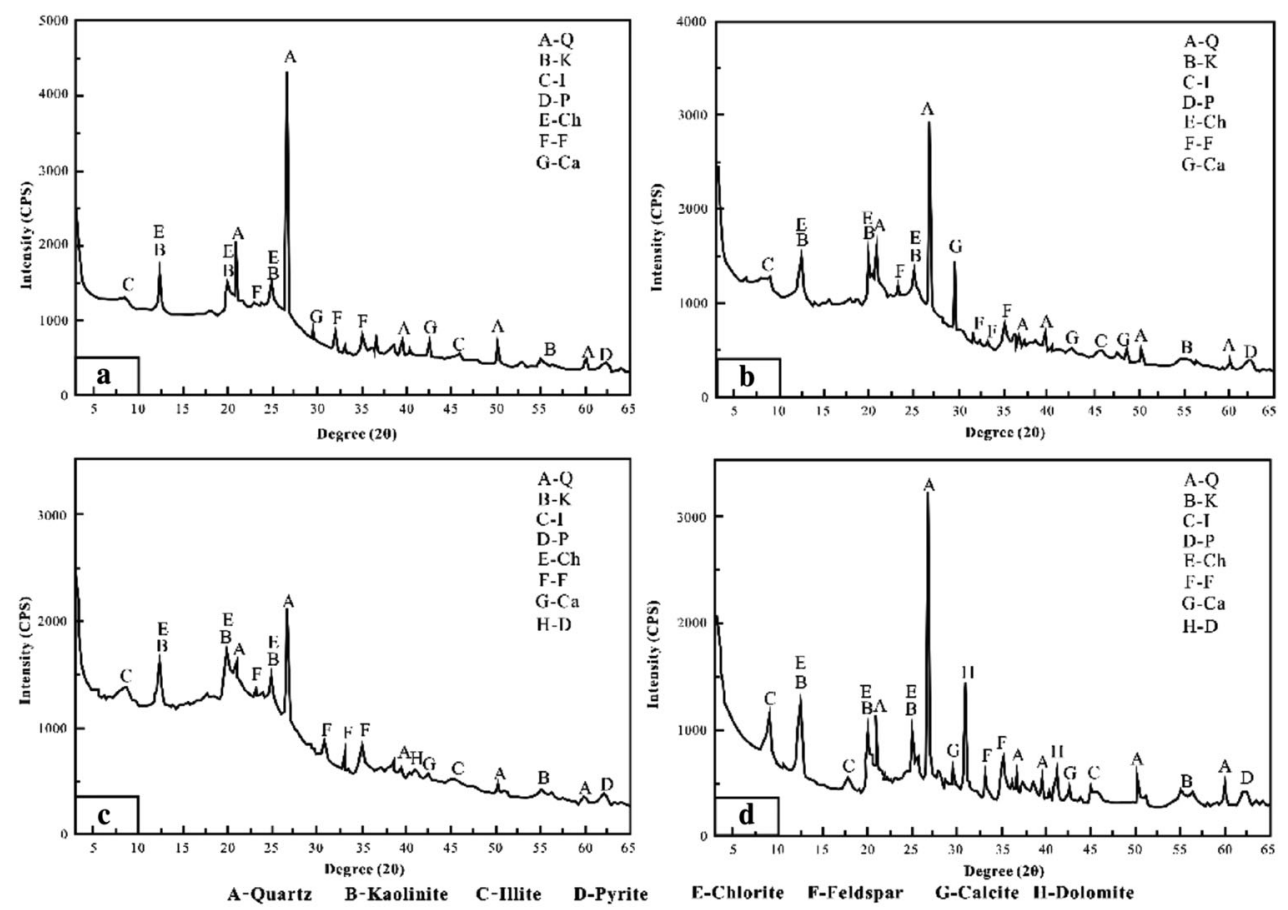

Fig. 4 XRD analysis on samples from Xishanyao Formation, Hanshuiquan district, Santanghu Coalfield, China

analyze the coal-forming swamp characteristics with the palynological assemblage characteristics in the research area (Table 2) (Diessel and Gammidge 1998). The latter parameters can reflect the vegetational forms of the coalforming swamp, and the changes of the swamp water coverage depth and the strength of the hydrodynamic force in the research area, so that the conclusion can be more accurate and more reliable (Souvik et al. 2016).

\subsubsection{Gelification of the coal-forming plants}

According to Fig. 5, the woody plants have the dominant contribution to the coal-forming swamp during the coalforming period of No. 8, 13, 14, 15, 18, 19 and 20 coal seams. The tissue of plants is well preserved. A large number of telinite, fusinites, and semifusinite can be observed in the microscopic observation. The woody plants and herbaceous plants are mixed in the coal-forming swamp of No. 9 coal seam during the coal-forming period, while the coal-forming swamps of No. 7, 17 and 22 coal seams are mainly made up of herbaceous plants. Compared with other coal-forming swamp consisted by woody plants with cellular structures are likely to break (Diessel and Gammidge 1998). The detrital components and desmocollinite are found in the microscopic observation. Meantime, the preservation degree of plant cells can be also reflected by BI (breaking index). However, the value of BI changes in small amplitude, which has little reference significance compared with TPI. In addition, the $\mathrm{pH}$ value of water body can be also indicated by the value of TPI. The activity of bacteria is weak in the water body with lower PH value, which plays a less important role in the decomposition of the remains of plants. In contrast, the activity of bacteria is intense in water body environment with higher $\mathrm{PH}$ value, and the cellular structure is seriously broke (Teichmüller 1989). Therefore, it can be inferred that the water environment in the coal-forming process is partial acid, and the structures of the plant cells are not well preserved on the whole through the TPI value of Xishanyao Formation at Hanshui district, Santanghu Coalfield (Fig. 5).

GI can be taken as the index to measure the degree of moisture in coal-forming swamp, the depth of water coverage and the strength of gelification, which is the specific value between the gelified components and the sum of the fusainisation and semi-fusainisation (Lamberson et al. 1991; Alkande et al. 1992; Diessel et al. 2000; Diessel 1992). The GI value of the major coal seams in the research area is highter than one, and the maximum value is up to fifty. The GI value in the middle and lower segments of No. 9 coal seam is relatively high, correspondingly, the content of vitrinite is higher than $80 \%$. This indicates that there develops a moist and closed swamp environment with deep water covered. The cellular structures were severely damaged and even disappeared in the case of intense gelification. The change of the water coverage depth in the coalforming swamp can be refected by VI, which is the specific 
Table 2 The parameters of coal-forming swamp in Hanshuiquan district, Santanghu Coalfield, NW China

\begin{tabular}{|c|c|c|c|c|c|c|c|c|c|c|c|c|}
\hline Sample & Coal seam & TPI & GI & GWI & VI & WI & $\mathrm{V} / \mathrm{I}$ & $\mathrm{F} / \mathrm{M}$ & OI & $\mathrm{TI}$ & BI & MI \\
\hline 1 & 7 & 0.54 & 2.49 & 0.21 & 0.64 & 0.5 & 2.45 & 0.55 & 0.2 & 0.42 & 0.4 & 0.5 \\
\hline 2 & 7 & 0.72 & 4.97 & 0.14 & 0.48 & 0.43 & 3.46 & 0.74 & 0.14 & 0.17 & 0.23 & 0.16 \\
\hline 3 & 7 & 0.85 & 1.86 & 0.09 & 0.54 & 0.49 & 2 & 0.88 & 0.04 & 0.1 & 0.18 & 0.11 \\
\hline 4 & 8 & 1.51 & 5.56 & 0.22 & 1.99 & 1.86 & 5.49 & 1.56 & 0.1 & 0.31 & 0.28 & 0.33 \\
\hline 5 & 8 & 1.16 & 8.63 & 0.25 & 1.71 & 1.68 & 8.74 & 1.17 & 0.08 & 0.27 & 0.16 & 0.26 \\
\hline 6 & 9 & 2.14 & 5 & 0.17 & 2.84 & 2.82 & 5 & 2.34 & 0.09 & 0.25 & 0.2 & 0.25 \\
\hline 7 & 9 & 1.53 & 3.89 & 0.29 & 0.25 & 0.23 & 3.89 & 1.55 & 0.02 & 0.3 & 0.23 & 0.31 \\
\hline 8 & 9 & 0.44 & 8.19 & 0.48 & 0.51 & 0.47 & 8.04 & 0.47 & 0.08 & 0.54 & 0.41 & 0.53 \\
\hline 9 & 9 & 0.27 & 50.11 & 0.27 & 0.28 & 0.27 & 50.11 & 0.28 & 0.01 & 0.28 & 0.24 & 0.26 \\
\hline 10 & 9 & 0.32 & 39.92 & 0.36 & 0.33 & 0.3 & 39.92 & 0.32 & 0.01 & 0.36 & 0.33 & 0.36 \\
\hline 11 & 9 & 0.63 & 4.95 & 0.19 & 0.76 & 2.84 & 5.2 & 0.64 & 0.05 & 0.19 & 0.28 & 0.21 \\
\hline 12 & 9 & 1.01 & 44.86 & 0.21 & 1.12 & 1.1 & 28.36 & 1.07 & 0.02 & 0.24 & 0.19 & 0.25 \\
\hline 13 & 13 & 2.13 & 11.47 & 0.16 & 2.48 & 2.41 & 8.58 & 2.17 & 0.04 & 0.17 & 0.22 & 1.21 \\
\hline 14 & 14 & 2.34 & 2.17 & 0.47 & 2.26 & 1.62 & 1.94 & 2.5 & 0.03 & 0.28 & 0.27 & 1.09 \\
\hline 15 & 14 & 1.01 & 4.93 & 0.32 & 1.03 & 0.99 & 5.07 & 1.05 & 0.07 & 0.33 & 0.31 & 0.34 \\
\hline 16 & 15 & 1.27 & 7.03 & 0.39 & 1.56 & 1.45 & 6.39 & 1.32 & 0.08 & 0.34 & 0.4 & 0.87 \\
\hline 17 & 17 & 0.98 & 2.48 & 0.12 & 0.89 & 0.87 & 3.18 & 0.99 & 0.11 & 0.11 & 0.11 & 0.14 \\
\hline 18 & 17 & 0.36 & 4.99 & 0.17 & 0.18 & 0.15 & 5.26 & 0.38 & 0.1 & 0.19 & 0.16 & 0.18 \\
\hline 19 & 18 & 2.25 & 1.89 & 0.09 & 2.63 & 2.61 & 4.25 & 2.29 & 0.09 & 0.11 & 0.21 & 0.1 \\
\hline 20 & 19 & 1.72 & 1.78 & 0.08 & 1.92 & 1.86 & 2.82 & 1.74 & 0.11 & 0.09 & 0.15 & 0.08 \\
\hline 21 & 20 & 1.4 & 1.88 & 0.11 & 1.46 & 1.4 & 5.31 & 1.41 & 0.08 & 0.13 & 0.23 & 0.13 \\
\hline 22 & 22 & 0.66 & 8.94 & 0.32 & 0.59 & 0.58 & 10.54 & 0.67 & 0.07 & 0.33 & 0.17 & 0.34 \\
\hline
\end{tabular}

$\overline{T P I}$ structure preservation index, $G I$ gelation index, $G W I$ groundwater flow index, $V I$ vegetation index, $W I$ forest index, $V / I$ mirror inert ratio, $F /$ $M$ bone base ratio, $O I$ oxygenation index, $T I$ transport index, $B I$ shatter index, $M I$ mobility index

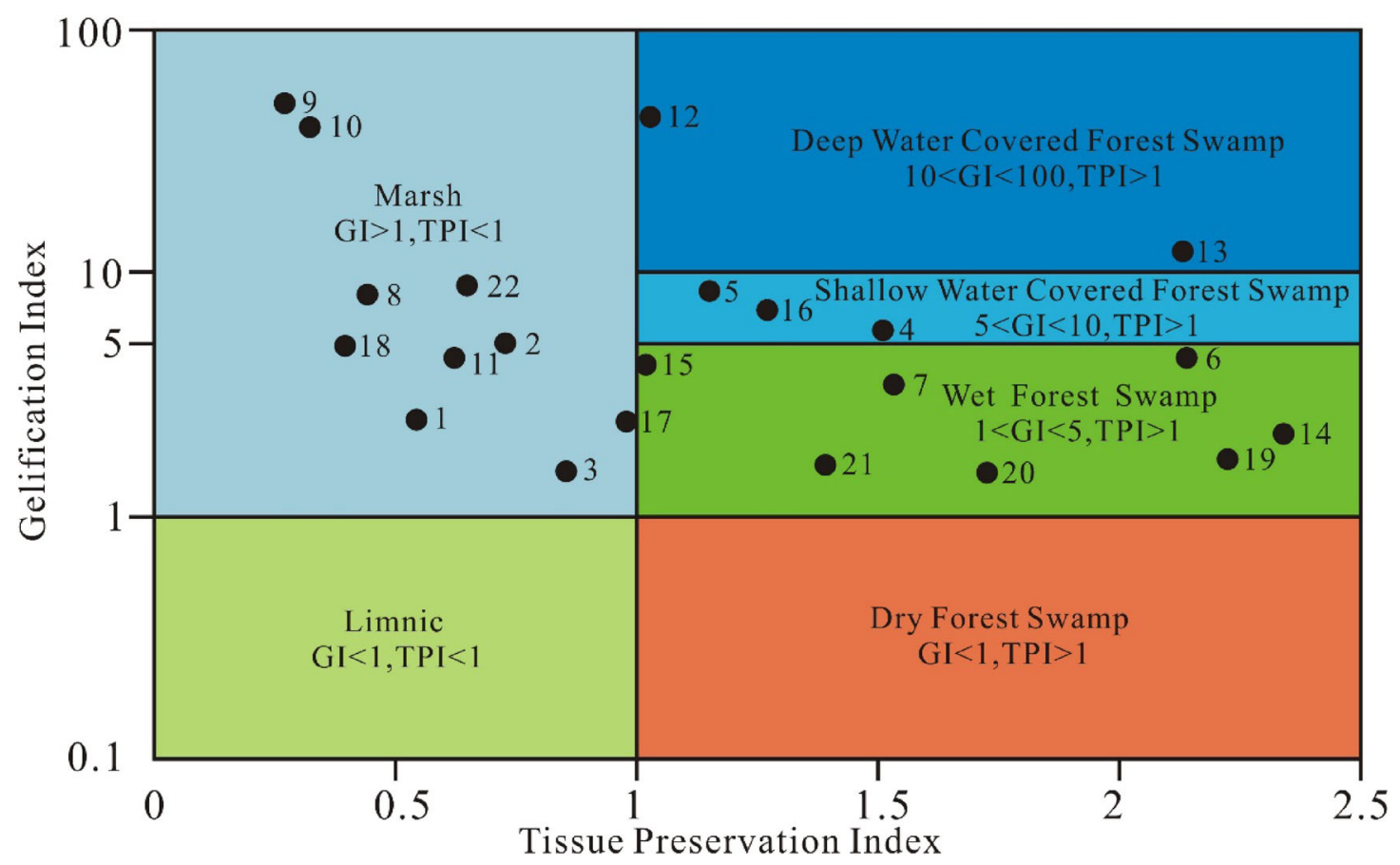

Fig. 5 Coa-forming swamp interpretation based on TPI and GI in Hanshuiquan district, Santanghu Coalfield, NW China. Modified by Diessel (1986) 
value between the contents of vitrinite and inertinite in maceral. The $\mathrm{V} / \mathrm{I}$ values in the middle and lower segments of No. 9 coal seam and No. 13 coal seam are higher than 10 , and the water coverage in the swamp is relatively deep during the coal-forming period. The V/I values of No. 8 , 15,22 coal seams and the top of No. 9 coal seam are varied from 5 to 10 . The coal-forming environment is moistshallow water coverage. The V/I values of No. 7, 14, 17, 18,19 and 20 coal seams vary from 1 to 5 , which signify the moist environment. This indicates that the coal-forming environment of Xishanyao Formation in Hanshuiquan district, Santanghu Coalfield is partial reducing environment with moist-shallow water covered on the whole.

According to the TPI-GI diagram (Fig. 5), it can be indicated that the changes of coal-forming swamp are relatively frequent in this research area. The coal-forming swamps are mainly in marsh, wet forest swamp facies, and shallow water forest swamp facies, followed by deep water covered forest swamp. The shallow water covered forest swamp facies only occurs in No. 9 coal seam (No. 12 sample) and No. 13 coal seam (No. 13 sample).

\subsubsection{Swamp change of the coal forming vegetation}

The GWI (Strobl et al. 2014) value of the test samples are all smaller than 0.5. It indicates that there is a light affection to the coal-forming swamp by the groundwater, and the coal-forming swamp water is covered by relatively shallow water. It is found that the telinite, telocollinite and desmocollinite in the samples with small GWI value are much more than the sum of gelocollinite, corpocollinite, vitrodetrinite and clay mineral through the microscopic observation. This indicates that the coal-forming swamp is less affected by the groundwater and has a weak hydrodynamic condition, which provides a good condition for the sustainable and stable development of the coal-forming swamp (Calder et al. 1991). MI, TI, and F/M can also reflect the strength of the water mobility in the coalforming swamp. According to the data analysis, it can be known that the water mobility at the top of No. 7 and 8 coal seam and No. 18 coal seam was intense during the coalforming period, and the remains of the plants had been damaged seriously. The number of the telinite is little (Silva et al. 2008). So, all these indicate that groundwater has less influence on the major coal seam of Xishanyao Formation in Hanshuiquan district, Santanghu Coalfield, which is not the decisive factor influencing the changes of coal-forming swamp.

VI shows the same rule to WI and TPI. The samples are uniformly distributed in the wetland swamp facies and wetland forest facies. Only a small number of samples are distributed in the wet swamp facies, wet forest facies and water covered forest facies. No. 7, 17 and 22 coal seams are made up of the herbaceous plants dominate in the coalforming plants, while the woody plants dominate the coalforming swamps of No. 8, 13, 14, 15, 18, 19 and 20 coal seams. No. 9 coal seam is the peat swamp mixed by woody plants and herbaceous plants. From bottom to top, the characteristics and evolution of coal-forming swamp is transited from forest facies to swamp facies (Fig. 6).

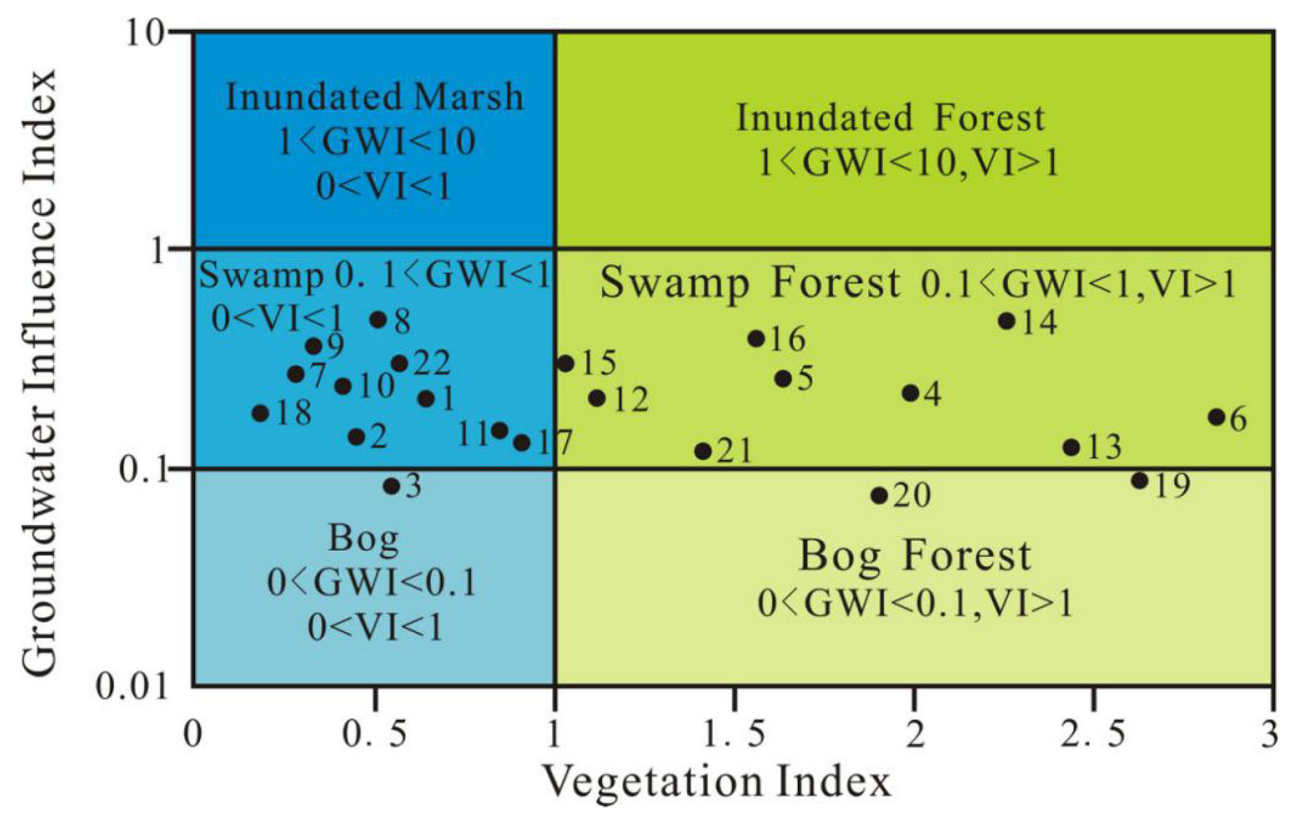

Fig. 6 Coal-forming swamp interpretation based on GWI and VI in Hanshuiquan district, Santanghu Coalfield, NW China. Modified by Calder et al. (1991) 


\subsubsection{Triangular chart}

The coal-forming swamp is divided into three categories, open swamp facies, wet forest forest swamp facies, and land forest swamp facies through the model constructed by calculating the values of $\mathrm{T}, \mathrm{D}$ and $\mathrm{F}$ (Mukhopadhyay 1989). The higher value of $T$ indicates the greater correlation between the coal-forming swamp type and the wet forest swamp facies. The land forest swamp facies is reflected by the high value of $F$. The great correlation between the coal-forming swamp and the open swamp facies is represented by the higher value of $\mathrm{D}$.

$\mathrm{T}=$ telinite + telocollinite

$\mathrm{F}=$ fusinite + semifusinite

$\mathrm{D}=$ vitrodetrinite + sporophore + liptodetrinite + cutinite + inertodetrinite + detrital mineral (clay mineral

+ quartz)

According to T-D-F triangular chart (Fig. 7), the samples are all near the wet forest swamp facies. Both F and D value are smaller than forty, while $\mathrm{T}$ value is relatively high. The $\mathrm{F}$ value of some samples is greater than $\mathrm{T}$ value. In other samples, the $F$ value is greater than $T$ value and $D$ value. It indicates that the dry environment indication is not obvious in this research area. The coal-forming swamp type is closely related to the wet forest swamp and open swamp. The open swamp and wet forest swamp interactively occur from top to bottom in the area.

\subsection{Characteristics of coal-forming swamp}

It can be confirmed that the coal-forming swamp type is the forest swamp facies covered by shallow water and wet forest swamp facies dominated by woody plants and the coal-forming swamp dominated by herbaceous plants based on T-D-F triangular chart, TPI-GI relation diagram, and GWI-VI relation diagram. In contrast, the deep water covered forest swamp facies is relatively few.

(1) Marsh facies: The maceral of coal-forming swamp in the research area is dominated by vitrinite, where the contents of desmocollinite, telocollinite, and vitrodetrinite are overwhelming. Therefore, it can be judged that the coal-forming plants are mainly in herbaceous plants like Osmundaceae and woody plants like Cyatheaceae. A great number of herbaceous plant sporopollens also occur in some coal seams. In this case, their cell structures are likely to be damaged in the coal-forming process. Therefore, there are relatively low contents of the telinite and the fusinite. In addition, the low peat swamp is supplied sufficiently by the surface water, which leads to huge ash content in the coal.

(2) Shallow water covered forest swamp facies: The coal-forming plants are dominated by evergreen needle-leaved plants like pine and cypress, and broad-leaved woody plants like Cycadaceae. The remains of plants are subjected to severe gelification due to the intense decomposition of anaerobic

D

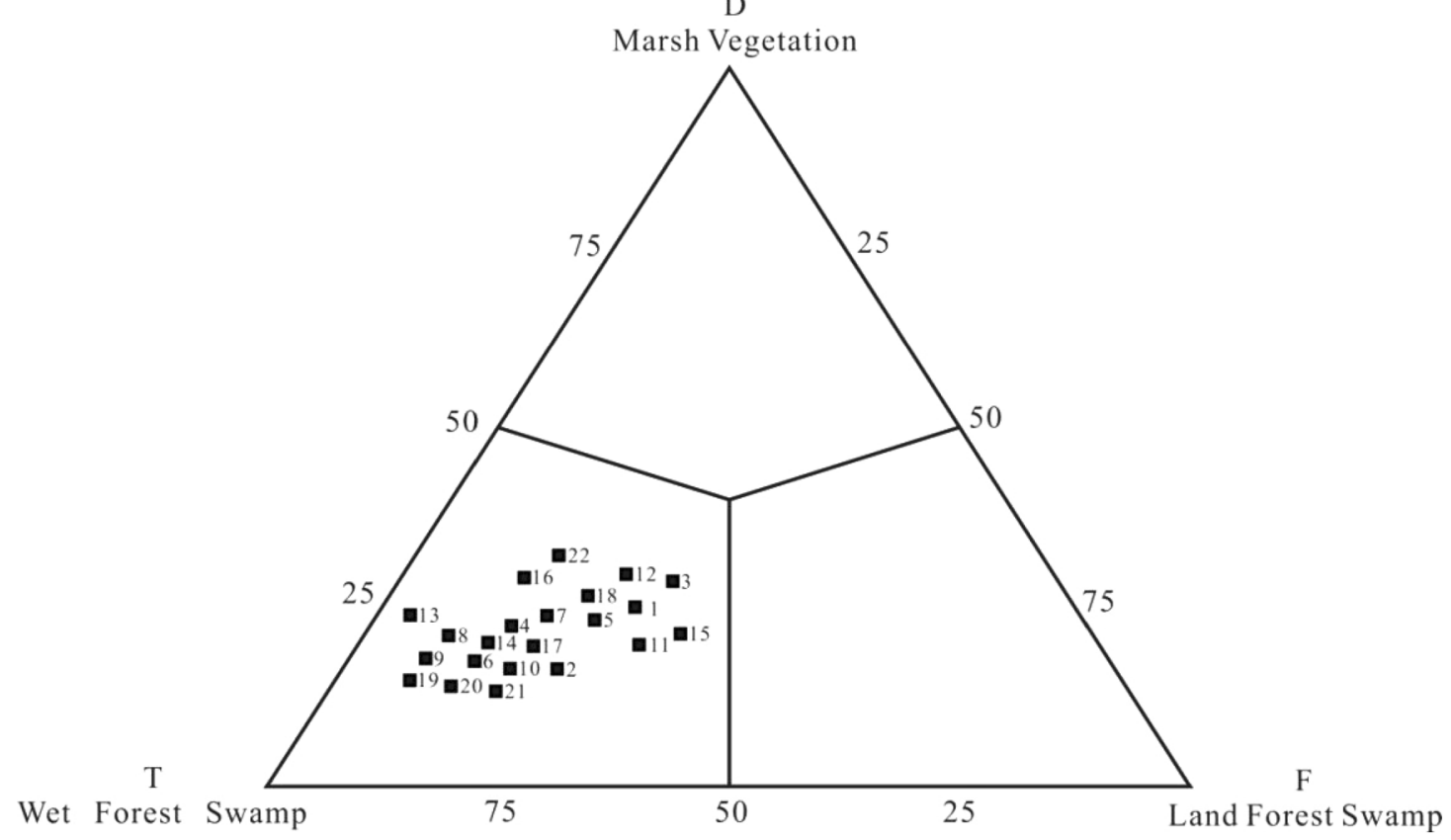

Fig. 7 Triangular chart of Coal-forming swamp in Hanshuiquan district, Santanghu Coalfield, NW China. Modified by Mukhopadhyay (1989) 
bacteria, and a large number of desmocollinite and telocollinite are formed in the weak hydrodynamic force environment, the high value of $\mathrm{T}$ increase in the triangular chart accordingly.

(3) Deep water covered forest swamp facies: It indicates that the peat swamp is less influenced by the oxidation and flow transfer through the high value of GI and the low value of GWI. The cellular structures of maceral are well preserved compared with other samples in the same coal seams.

(4) Wet forest swamp facies: There are high value of TPI, VI, WI and low value of GI and GWI in this coal-forming swamp, which content of the inertinite is higher than the other kinds of forest swamp facies, and the coal-forming plants are mainly made up of Cyatheaceae and Pinaceae.

\section{Vertical evolution characteristics}

Three periodic cycles transiting from forest swamp to low herbaceous swamp from bottom to top are found in Hanshuiquan district, Santanghu Coalfield (Fig. 8). The rule progressively transiting from wet swamp to relatively shallow-deep water covered swamp is reflected from bottom to top in the forest swamp. The development of coalforming swamp has the fluctuation characteristics. Three changes of shallow-deep-shallow of water are found in the coal-forming swamp from the bottom to the top. The gelification also went through a process of weak-intenseweak.

No. 9 coal seam is the most important coal seam in the Santanghu Coalfield. The coal-forming swamp type went through a process from herbaceous swamp to woody swamp, and the water body shows the change rule from shallow to deep then to shallow. The TPI develops from small to large, and the middle part of No. 9 coal seam has the great value of GWI. It indicates that the cellular structure of the coal petrography formed in the herbaceous plant swamp is easy to be destroyed by the strong power of groundwater.

In addition, the sporopollen number of woody plants in vertical direction shows three cycles changes firstly increasing and then decreasing (Fig. 8), which is totally identical with the rules reflected by the VI, WI and TPI index. The rule of the changes in herbaceous plant sporopollen is contrary to that of the woody plant sporopollen. The type of the original coal-forming swamp can be accurately characterized by the types and contents of

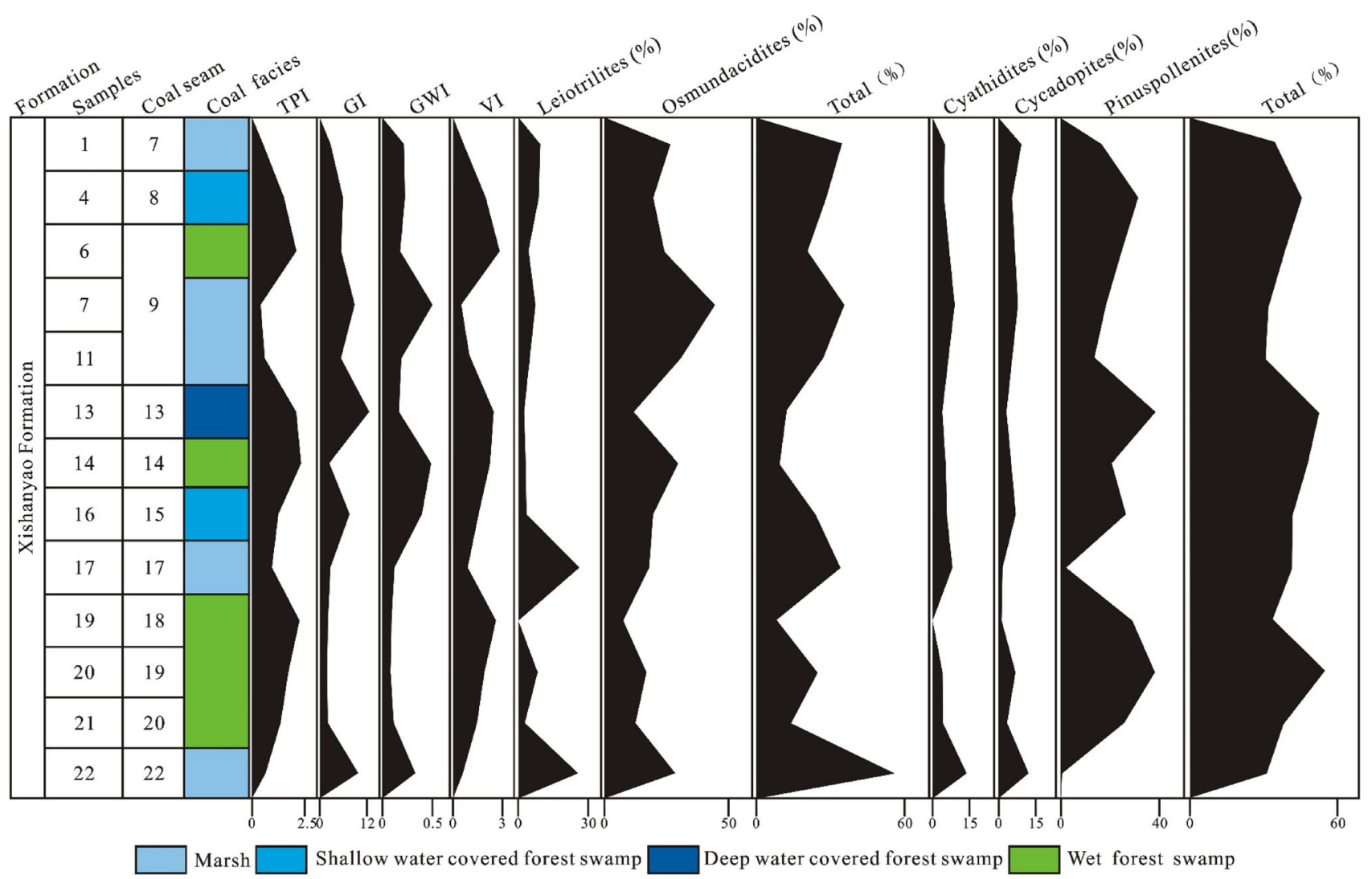

Fig. 8 The variation of coal-forming swamp parameters and sporopollens in Hanshuiquan district, Santanghu Coalfield, NW China 
different sporopollens. The contents of the woody plant sporopollen are great in the No. 8 coal seam, No. 13, No. 19 coal seam and the upper of No. 9 coal seam. It indicates that the woody plants occupy the leading position in the coal forming period. The large contents of herbaceous plant sporopollen occur in the No. 7 coal seam, the middle of No. 9 coal seam, No. 17 coal seam and No. 22 coalseam. It indicates that the coal-forming swamp is provided the main raw material by herbaceous plants. The other coal seams are mainly in the swamps mixed by herbaceous plants and woody plants.

The coal-forming swamps are mainly composed of herbaceous plants like Lygodiaceae (0\%-28.6\%) and Osmundaceae $(7.7 \%-43.4 \%)$ as well as woody plants like Cyatheaceae (0\%-14.3\%), Cycadaceae (1.9\%-14.3\%) and Pinaceae $(0 \%-38.6 \%)$ through the test results of the sporopollen (Fig. 8). The No. 7, 9 and 14 coal seams evolved from the coal-forming swamps dominated by Osmundaceae. No. 8, 13, 15, 18, 19 and 20 coal seams evolved from the coal-forming swamps dominated by pine and cypress. No. 17 coal seam evolved from the coalforming swamp dominated by Lygodiaceae, and No. 22 coal seam evolved from the coal-forming swamp jointly dominated by Osmundaceae and Lygodiaceae.

The palynological assemblage type of the Xishanyao Formation is dominated by Leiotriletes-Cyathidites-Osmundacidites-Cycadopites-Pinuspollenites. Osmundacidite remains dominant in ferns, and it reached the progenitive peak in Mesozoic, especially in Early and Middle Jurassic. The content of Cyathidites significantly increases, which is the typical plant in the Jurassic (Liu 2008), and the content of Pinuspollenites dominated in gymnosperm (Deng 2007).

Cyatheaceae, Lycopodium, Selaginella and other herbaceous tree ferns have no secondary xylem tissue or poor developed, while the parenchyma and epidermal cells mainly develop. These tissues cannot be preserved because of the poor resistant ability to decomposition, so in the wet and reduction environment, they can easily evolve into to the desmocollinite and clastic maceral. The secondary xylem tissue stems of the woody gymnosperms like fir, ginkgo, pine and cypress as well as Cycadaceae are well developed, and they cannot be decomposed or destroyed. In moist and reducing environemnt, they can easily envolve into the telinite and telocollinite (Zhang and Wu 1995; Wang et al. 1997).

In the early period of Middle Jurassic, the warm and moist climate was suitable for the plant growth. The moist degree for coal-forming swamp varies from paludose to mesophyte. The plants in mesophyte environment are all Pinaceae, and they can resist the drought of short time (Du 2015). The tall needle-leaved plants such as Pinaceae and Podocarpaceae accompanied by Cycadaceae, Araucariaceae and other broad-leaved evergreen plants grew in the alpine zone. The scrubby Cyatheaceae widely grew at the shore of the lake (Deng 2007; Du 2015; Maria et al. 2015; Wang et al. 2005; Yang et al. 2006). All these shows an ancient ecosystem with alpine zone and vast lake.

\section{Conclusion}

(1) The vitrinite is the most significant maceral in the major coal seam of Xishanyao Formation in Hanshuiquan district, Santanghu Coalfield, with higher content than $60 \%$. Inertinite occupies the secondary position, and its content is less than $40 \%$. A small amount of exinite can be discovered in most samples under fluorescence. The content of vitrinite in bright coal usually more than $80 \%$.

(2) Three periodic cycles transiting from forest swamp to low herbaceous swamp from bottom to top are found Hanshuiquan district, Santanghu Coalfield. The development of coal-forming swamp has the fluctuation characteristics. Three changes of shallow-deep-shallow of water are found in the coalforming swamp from the bottom to the top.

(3) The palynological assemblage type of the Xishanyao Formation is dominated by Leiotriletes-CyathiditesOsmundacidites-Cycadopites-Pinuspollenites. The No. 7, 9 and 14 coal seams envolved from the coal-forming swamps dominated by Osmundaceae. No. 8, 13, 15, 18, 19 and 20 coal seams evolved from the coal-forming swamps dominated by pine and cypress. No. 17 coal seam evolved from the coalforming swamp dominated by Lygodiaceae, and No. 22 coal seam evolved from the coal-forming swamp jointly dominated by Osmundaceae and Lygodiaceae. The environment of coal-forming swamp shows an ancient ecosystem with alpine zone and vast lake.

Open Access This article is distributed under the terms of the Creative Commons Attribution 4.0 International License (http://crea tivecommons.org/licenses/by/4.0/), which permits unrestricted use, distribution, and reproduction in any medium, provided you give appropriate credit to the original author(s) and the source, provide a link to the Creative Commons license, and indicate if changes were made.

Funding Funding was provided by National Natural Science Foundation Project (Grant No. 41662010) and Xinjiang Uygur Autonomous Region University Scientific Research Program For Young Teachers Research And Cultivation Fund Project (Grant No. XJEDU2016S038). 


\section{References}

Alimujiang T, Zhuang XG, Zhao YW et al (2014) Coal petrology and coal facies analysis of Xiaoxigou mine in Southern Junggar Coalfield, Xinjiang. Xinjiang Geol 32(4):525-529 (in Chinese with English abstract)

Alkande SO, Hoffknecht A, Erdtmann BD (1992) Rank and petrographic composition of selected Upper Cretaceous and Tertiary coals of southern Nigeria. Int J Coal Geol 20:209-224

An Q, Ma FZ (2013) Analysis and evaluation on coal characteristics of 9-1 coal seam in Hanshuiquan exploration district of Santanghu coalfield in Xinjiang. West-China Exploration Engineering, pp 118-123 (in Chinese with English abstract)

Ao WH, Huang WH, Weng CM et al (2012) Coal petrology and genesis of Jurassic coal in the Ordos Basin, China. Geosci Front 3(1):85-95

Calder J, Gibling M, Mukhopadhyay P (1991) Peat formation in a Westphalian B piedmont setting, Cumberland basin, Nova Scotia: implications for the maceral-based interpretation of rheotrophic and raised paleomires. Bull Soc Geol Fr 162(2):283-298

Dai SF, Ren DY, Li SS et al (2007) Coal facies evolution of the main minable coal-bed in the Heidaigou Mine, Jungar Coalfield, Inner Mongolia, northern China. Sci China Ser D Earth Sci 50(2):144-152

Dai SF, Wang XB, Seredin VV et al (2012) Petrology, mineralogy, and geochemistry of the Ge-rich coal from the Wulantuga Ge ore deposit, Inner Mongolia, China: new data and genetic implications. Int J Coal Geol 90:72-99

Dai SF, Yang JY, Ward CR et al (2015a) Geochemical and mineralogical evidence for a coal-hosted uranium deposit in the Yili Basin, Xinjiang, northwestern China. Ore Geol Rev 70:1-30

Dai SF, Hower JC, Ward CR et al (2015b) Elements and phosphorus minerals in the middle Jurassic inertinite-rich coals of the Muli Coalfield on the Tibetan Plateau. Int J Coal Geol 144:23-47

Deng SH (2007) Palaeoclimatic implications of main fossil plants of the Mesozoic. J Palaeogeogr 9(6):559-574 (in Chinese with English abstract)

Diessel CFK (1982) An appraisal of coal facies based upon maceral characteristics. In: Symposium proceedings-Geological Society of Australia Inc. Coal Group 4, pp 474-483

Diessel CFK (1986) On the correlation between coal facies and depositional environments. 20th Newcastle symposium on "Advances in the Study of the Sydney Basin". In: Publication proceedings, vol 246. Department of Geology, University of Newcastle, Australia, pp 19-22

Diessel CFK (1992) Coal-bearing depositional systems. Springer, Berlin, p 721

Diessel CFK, Gammidge L (1998) Isometamorphic variations in the reflectance and fluorescence of vitrinite: a key to depositional environment. Int J Coal Geol 36:167-222

Diessel C, Boyd R, Wadsworth J et al (2000) On balanced and unbalanced accommodation/peat accumulation ratios in the Cretaceous coals from Gates Formation, Western Canada, and their sequence-stratigraphic significance. Int $\mathrm{J}$ Coal Geol 43(1): $143-186$

Du XQ (2015) Characteristics of Jurassic plant fossils and floras in North China and the implication of paleoclimate change. China University of Geoscience, Beijing (in Chinese with English abstract)

Du G, Zhuang XG, Querol X et al (2009) Ge distribution in the Wulantuga high-germanium coal deposit in the Shengli coalfield, Inner Mongolia, northeastern China. Int J Coal Geol 78(1):16-26
Fu HJ, Tang DZ, Xu H et al (2016) Geological characteristics and CBM exploration potential evaluation: a case study in the middle of the southern Junggar Basin, NW China. J Nat Gas Sci Eng 30:557-570

Ge X, Fan Y, Li J et al (2015) Pore structure characterization and classification using multifractal theory-an application in Santanghu basin of western China. J Pet Sci Eng 127:297-304

Gmur D, Kwiecińska BK (2002) Facies analysis of coal seams from the Cracow Sandstone Series of the Upper Silesia Coal Basin, Poland. Int J Coal Geol 25:29-44

Gorbanenko O, Ligouis B (2015) Variations of organo-mineral microfacies of Posidonia Shale from the Lower Saxony Basin and the West Netherlands Basin: application to paleoenvironmental reconstruction. Int J Coal Geol 152:78-99

Hackleya PC, Fishman N, Wu T, Baugher G (2016) Organic petrology and geochemistry of mudrocks from the lacustrine Lucaogou Formation, Santanghu Basin, northwest China: application to lake basin evolution. Int J Coal Geol 168:1-15

He P, Wang FY, Zhao CY (1995) Suberinite in Jurassic source rocks of Xinjiang. Xinjiang Petroleum Geology 16(4):301-306 (in Chinese with English abstract)

Huang P (2002) Middle Jurassic sporopollen assemblages from Tangqian-3 well of the Santanghu Basin, Xinjiang. Acta Micropalaeontol Sin 19(2):178-192

Huang C (2014) Mode of occurrence and geologicai. Qrigin of arsenic in coai from sanTanghu basin. Xinjiang University

Huang C, Tian JJ (2013) Research progress of arsenic occurrence in coal in China. West-china Explor Eng 25(7):100-103

Huang WH, Tanh SH, Tang XY et al (2010) The Jurassic coal petrology and the research significance of Northwest China. Coal Geol Explor 38(4):1-6 (in Chinese with English abstract)

Jiang GB (2003) The studies of Jurassic sedimentary system in Santanghu Basin. Northwest University (in Chinese with English abstract)

Kalaitzidis S, Siavalas G, Skarpelis N, Araujo CV, Christanis K (2009) Late Cretaceous coal overlying karstic bauxite deposits in the Parnassus-Ghiona Unit, Central Greece: coal characteristics and depositional environment. Int J Coal Geol 81:211-226

Kalkreuth W, Marchioni DL, Calder JH, Lambertson MN, Naylor RD, Paul J (1991) The relationship between coal petrography and depositional environments from selected coal basins in Canada. Int J Coal Geol 19:21-76

Kalkreuth W, Marchioni D, Utting J (2000) Petrology, palynology, coal facies and depositional environments of an Upper Carboniferous coal seam, Minto Coalfield, New Brunswick, Canada. Can J Earth Sci 37:1209-1228

Lamberson MN, Bustin RM, Kalkreuth W (1991) Lithotype (maceral) composition and variation as correlated with paleo-wetland environments. Gates Formation, Northeastern British Columbia, Canada. Int J Coal Geol 18:87-124

Li J, Zhuang XG, Querol X et al (2012a) High quality of Jurassic coals in the southern and eastern Junggar coalfields, Xinjiang, NW China: geochemical and mineralogical characteristics. Int J Coal Geol 99:1-15

Li J, Zhuang XG, Zhou JB et al (2012b) Coal facies characteristic and identification of transgressive/regressive coal-bearing cycles in a thick coal seam of Xishanyao Formation in Eastern Junggar Coalfield, Xinjiang. J Jilin Univ (Earth Science Edition) 42(2):104-114 (in Chinese with English abstract)

Li BQ, Zhuang XG, Li J et al (2014) Geological controls on coal quality of the Yili Basin, Xinjiang, Northwest China. Int J Coal Geol 131:186-199

Liang H, Li XN, Ma Q et al (2014) Geological features and exploration potential of Permian Tiaohu Formation tight oil, Santanghu Basin, NW China. Pet Explor Dev 41(5):616-627 
Liu CL (2008) The Early Jurassic stratigraphy and sporopllen assemblages of the central depression in the Junggar Basin. Northwest University (in Chinese with English abstract)

Liu B, Lu YF, Zhao R et al (2012a) Formation overpressure and shale oil enrichment in the shale system of Lucaogou Formation, Malang Sag, Santanghu Basin, NW China. Pet Explor Dev 39(6):744-750

Liu YQ, Jiao X, Li H et al (2012b) Primary dolostone formation related to mantle-originated exhalative hydrothermal activities, Permian Yuejingou section, Santanghu area, Xinjiang, NW China. Sci China Earth Sci 55(2):183-192

Liu B, Lu YF, Meng YL et al (2015) Petrologic characteristics and genetic model of lacustrine lamellar fine-grained rock and its significance for shale oil exploration: a case study of Permian Lucaogou Formation in Malang sag, Santanghu Basin, NW China. Pet Explor Dev 42(5):656-666

Ma J, Huang ZL, Liang SJ et al (2016a) Geochemical and tight reservoir characteristics of sedimentary organic-matter-bearing tuff from the Permian Tiaohu Formation in the Santanghu Basin, Northwest China. Mar Pet Geol 73:405-418

Ma J, Huang ZL, Zhong DK et al (2016b) Formation and distribution of tuffaceous tight reservoirs in the Permian Tiaohu Formation in the Malang sag, Santanghu Basin, NW China. Pet Explor Dev 43(5):778-786

Maria B, Zoltán P, Emese B et al (2015) Palaeotopography related plant succession stages in a coal forming deltaic succession in early Jurassic in Hungary. Palaeogeogr Palaeoclimatol Palaeoecol 440:579-593

Mukhopadhyay P (1989) Organic petrography and organic geochemistry of tertiary coals from Texas in relation to depositional environment and hydrocarbon generation. Report of investigations. Bureau of Economic Geology, Texas

Nie HG, Zhao FH, Li YH (2016) Analysis on coal facies characteristics of Jurassic Coal in Turpan-Hami Basin, Xinjiang. Xinjiang Geol 34(1):144-149 (in Chinese with English abstract)

Pang QF, Zhuang XG, Li JF et al (2012) Petrographical, chemical and geochemical characteristics of Jurassic coal in western Chaoshui Basin, Inner Mongolia. Geol Sci Technol Inf 31(1):27-32 (in Chinese with English abstract)

Silva MB, Kalkreuth W, Holz M (2008) Coal petrology of coal seams from the Leão-Butiá Coalfield, Lower Permian of the Paraná Basin, Brazil-implications for coal facies interpretations. Int $\mathrm{J}$ Coal Geol 73:331-358

Song DF, He DF, Wang SR (2013) Source rock potential and organic geochemistry of carboniferous source rocks in Santanghu Basin, NW China. J Earth Sci 24:355-370

Souvik S, Sumon N, Satyabrata D (2016) Discussion on the concepts in paleoenvironmental reconstruction from coal macerals and petrographic indices. Mar Pet Geol 73:371-391

Strobl SAI, Sachsenhofer RF, Bechtel A, Meng Q (2014) Paleoenvironment of the eocene coal seam in the Fushun basin (NE China): implications from petrography and organic geochemistry. Int J Coal Geol 134-135:24-37
Teichmüller M (1989) The genesis of coal from the viewpoint of coal petrology. Int J Coal Geol 12:1-87

Teichmüller M, Teichmüller R (1982) The geological basis of coal formation. In: Stach E et al (eds) Stach's textbook of coal petrology, 3rd edn. Borntraeger, Berlin, pp 5-86

Wang SJ, Tang XY, Zhang J et al (1997) Jurassic coal-forming plants in Tuha Basin and its relationship with oil from coal. Coal Geol Explor 6:26-28 (in Chinese with English abstract)

Wang YD, Mosbrugger V, Zhang H (2005) Early to Middle Jurassic vegetation and climatic events in the Qaidam Basin, Northwest China. Palaeogeogr Palaeoclimatol Palaeoecol 224(1):200-216

Wang SS, Liu YQ, Zhang HF et al (2015) Geochemical characteristics and tectonic setting of the Middle Permian Tiaohu Formation mafic-ultramafic rocks of Santanghu area, Xinjiang, Northwest China. Sci China Earth Sci 58(11):1924-1938

Wang ZD, Liang M, Qian Y et al (2016) The oxygen-bearing geolipids in the Lucaogou shale of Upper Permian, Santanghu Basin, China. Org Geochem 102:59-66

Wei YJ (2002) Preliminary study on low-rank coal reservoirs and coalbed methane pool forming in Zhungaer Basin, NWChina. China University of Geoscience, Beijing (in Chinese with English abstract)

Xiao WJ, Windley BF, Badarch G, Sun S, Li JL, Qin KZ, Wang ZH (2004a) Palaeozoic accretionary and convergent tectonics of the southern Altaids: implications for the lateral growth of Central Asia. J Geol Soc 161:339-342

Xiao WJ, Zhang LC, Qin KZ, Sun S, Li JL (2004b) Paleozoic accretionary and collisional tectonics of the Eastern Tianshan (China): implications for the continental growth of central Asia. Am J Sci 304:370-395

Yang P, Xie ZK, Yuan XJ et al (2006) Palaeoecological characteristics and its palaeogeographic significance of the Jurassic in northern margin of Qaidam Basin. J Palaeogogr 8(2):165-173 (in Chinese with English abstract)

Zhang Q, Wu JJ (1995) Cprrelations between macerals and paleosporopollen types within coal seam in Huanglong Coalfield. Coal Geol Explor 24(1):15-19 (in Chinese with English abstract)

Zhang WB, Zhong NN, Dai SF (2000) Origin of "exceptional" Jurassic coal-derived oil in Santanghu Basin. J China Univ Min Technol 2:103-106

Zhang J, Wei B, Tian JJ et al (2015) Characteristics of coal quality and coal facies of Middle-Lower Jurassic coal seam in large ready coalfield of the Santanghu Basin, Hami, Xinjiang. Acta Geol Sin 89(5):917-930 (in Chinese with English abstract)

Zhang YY, Tian JJ, Feng S et al (2018) The occurrence modes and geologic origins of arsenic in coal from Santanghu Coalfield, Xinjiang. J Geochem Explor 186:225-234

Zhou JB, Zhuang XG, Alastuey A et al (2010) Geochemistry and mineralogy of coal in the recently explored Zhundong large coal field in the Junggar basin, Xinjiang province, China. Int J Coal Geol 82(1):51-67 